\title{
Understanding molecular recognition and epitope prediction from Information Theoretic approach
}

\author{
Indranil Mitra ${ }^{*}$, Yan Cui ${ }^{2}$ \\ From UT-ORNL-KBRIN Bioinformatics Summit 2010 \\ Cadiz, KY, USA. 19-21 March 2010
}

\section{Background}

Cellular immunity is dependent on T-cell recognition of peptide/major histocompatibility complex (MHC) and is a critical molecular recognition component [1]. A large class of bioinformatics tools facilitates the identification of T-cell epitopes to specific MHC alleles. However, not all peptide residues contribute equally or are relevant to binding due to polymorphism of genes encoding MHC, making development of statistical methods difficult. Information Theory has proved to be one of the most universal mathematical theories that governs virtually all processes [2]. The success of this approach in analyzing a huge range of engineering, technological and natural processes is impressive. In Molecular Biology the applications have been very successful at the sequence level, many sequence comparison and binding site identification methods now boasts a sound information theoretic foundation.

\section{Materials and methods}

In this work we have developed a mathematical formalism for applying information theory in identifying an explicit computational strategy and developing algorithms for the study of peptide/MHC interactions through epitope predictions. A sampling method has been initiated to circumvent the binding problem. Comparisons have been made with existing Machine Learning Methods and a validation of the efficiency of the model may be tested $[3,4]$.The results will have significant impact for understanding the immune system and for rational drug design [5].

\footnotetext{
* Correspondence: aimitra@clemson.edu

'Department of Mathematical Sciences, Clemson University, E-006 Martin Hall, Clemson, SC 29631, USA
}

\begin{abstract}
Acknowledgments
This work was partially supported by DOD grant W81XHW-05-01-0227 received by YC. Authors would also like to thank Dr. IrisAntes, Technical University, Munich for helpful discussions.
\end{abstract}

\section{Author details}

${ }^{1}$ Department of Mathematical Sciences, Clemson University, E-006 Martin Hall, Clemson, SC 29631, USA. ²Department of Molecular Sciences \& Center of Integrative and Translational Genomics, University of Tennessee Health Science Center, 858 Madison Ave. Memphis, TN 38163, USA.

\section{Published: 23 July 2010}

\section{References}

1. Lin HH, Zhang GL, Tongchusak S, Reinherzand EL, Brusic V: Evaluation of MHC-II peptide binding prediction servers: applications for vaccine research. BMC Bioinformatics 2008, 9(Suppl 12):S12-S22.

2. Adami C: Physics of Life Reviews. 2004, 1.

3. O'Brien PJ, Herschlag D: Catalytic promiscuity and the evolution of new enzymatic activities. Chem Biol 1999, 6:R91-R105.

4. Tong JC, Tan TW, Ranganathan S: Methods and Protocols for Prediction of Immunogenic Epitopes. Brief Bioinform 2007, 8(2):96-108.

5. Wang P, Sidney J, Dow C, Moth B, Sette A, Peters B: A Systematic Assessment of MHC Class II Peptide Binding Predictions and Evaluation of a Consensus Approach. PLoS Comput Biol 2008, 4(4):e1000048.

doi:10.1186/1471-2105-11-S4-P22

Cite this article as: Mitra and Cui: Understanding molecular recognition and epitope prediction from Information Theoretic approach. BMC Bioinformatics 2010 11(Suppl 4):P22.

Submit your next manuscript to BioMed Central and take full advantage of:

- Convenient online submission

- Thorough peer review

- No space constraints or color figure charges

- Immediate publication on acceptance

- Inclusion in PubMed, CAS, Scopus and Google Scholar

- Research which is freely available for redistribution 